\title{
PROFIL SISWA AUTIS DALAM PEMBELAJARAN MATEMATIKA DI FILIAL SLBN BEKASI JAYA
}

\author{
Syarifah Komala Dewi ${ }^{1)}$ dkk dan Rahmita Nurul Muthmainnah ${ }^{2)}$ \\ Universitas Muhammadiyah Jakarta \\ 1) syarifahkomala@gmail.com \\ 2)rahmita_nurul@yahoo.co.id
}

\begin{abstract}
Abstrak
Penelitian ini bertujuan untuk melihat profil siswa autis kelas 11 di Filial SLBN Bekasi Jaya dalam proses pembelajaran matematika. Penelitian ini tergolong penelitian deskriptif kualitatif dengan menggunakan teknik observasi dan wawancara, subjek pada penelitian ini adalah siswa autis kelas 11 di Filial SLBN Bekasi Jaya yang berjumlah 1 orang siswa laki-laki (subjek M). Penelitian ini dilakukan dalam beberapa tahapan dari tahapan pra-lapangan, tahapan lapangan/tahapan penelitian, dan tahapan penulisan laporan. Data yang telah terkumpul kemudian di analisis secara deskriptif. Hasil penelitian menunjukkan bahwa siswa autis masih sangat bergantung pada guru salah satunya ialah masih membutuhkan bimbingan dari guru kelas dalam setiap mengerjakan soal latihan. Ia belum bisa mengerjakannya secara individu. Sehingga diperlukan waktu khusus bagi guru untuk membimbing siswa tersebut dalam mengerjakan soal hitung matematika.
\end{abstract}

Kata kunci: Pembelajaran Matematika, Siswa Autis, ABK

\section{PENDAHULUAN}

Anak berkebutuhan khusus adalah anak yang dalam proses pertumbuhan/ kembangannya secara signifikan mengalami kelainan/penyimpangan (fisik, mental, elektual, sosial, emosi, emosional) dibandingkan anak-anak lain seusianya sehingga mereka memerlukan pelayanan pendidikan secara khusus. Anak berkebutuhan khusus memiliki karakteristik yang berbeda-beda, berdasarkan kelainan yang mereka miliki, salah satunya adalah anak autis.

Anak autis merupakan anak yang hanya tertarik pada dunianya sendiri, mereka tidak peduli dengan stimulus-stimulus yang datang dari orang lain atau keadaan yang ada disekitarnya. Perilakunya timbul semata-mata karena dorongan dari dalam dirinya. 
Interaksi merupakan suatu modal bagi seseorang untuk memperoleh berbagai informasi melalui lingkungan. Lingkungan sampai saat ini diyakini sebagai sumber yang sangat berpengaruh terhadap perkembangan seseorang, jika seseorang mengalami hambatan dalam interaksi dan komunikasi, maka orang tersebut akan mengalami hambatan dalam kegiatan belajarnya.

Autisme merupakan kelainan yang serius dan kompleks, apabila tidak ditangani dengan tepat dan cepat kelainan ini akan menetap dan dapat berakibat pada keterlambatan perkembangan. Keterlambatan perkembangan pada kasus autis biasanya ditemukan pada anak-anak dan mempunyai dampak yang berlanjut sampai dewasa. Salah satu gangguan perkembangan yang dialami adalah kesulitan dalam memahami apa yang mereka lihat, dengar, dan rasakan. Gangguan ini dapat menyebabkan keterlambatan perkembangan antara lain dalam kemampuan berkomunikasi, berbicara, bersosialisasi, perilaku, dan keterampilan motorik.

Pendidikan merupakan hak bagi setiap warga negara untuk mengikutinya. Tujuan dari pendidikan adalah membentuk manusia yang berakhlak, cerdas berilmu serta dapat mengembangkan potensi yang ada pada dirinya dan dapat direalisasikan dalam kehidupan di masyarakat. Dalam Undang-Undang Nomor 20 Tahun 2003 tentang sistem pendidikan pasal 5 ayat 1 menyatakan bahwa "Setiap warga negara mempunyai hak yang sama untuk memperoleh pendidikan yang bermutu" dan pasal 5 ayat 2 yang menyatakan bahwa "Warga negara yang memiliki kelainan fisik, emosional, mental, intelektual, dan/atau sosial berhak memperoleh pendidikan khusus". Hal tersebut menunjukkan bahwa setiap anak, termasuk anak berkebutuhan khusus, berhak memperoleh pendidikan yang layak.

Pendidikan luar biasa, seperti yang termuat dalam UU nomor 20 tahun 2003 tentang Sistem Pendidikan Nasional, pasal 50: menjelaskan bahwa pendidikan diarahkan pada pengembangan sikap dan kemampuan kepribadian anak, bakat, kemampuan mental, dan fisik sampai mencapai potensi mereka yang optimal. Pendidikan Luar Biasa bertujuan membekali siswa berkebutuhan khusus untuk dapat berperan aktif di dalam masyarakat. Pemerintah menawarkan berbagai sekolah SLB diantaranya SLB-A, SLB-B, SLB-C, dan SLB-D.

Disamping itu, pada Bab VI Pasal 19 Peraturan Pemerintah No. 19 Tahun 2005 dikatakan bahwa proses pembelajaran pada satuan pendidikan diselenggarakan secara interaktif, inspiratif, menyenangkan, menantang, memotivasi peserta didik untuk berpartisipasi aktif, serta memberikan ruang yang cukup bagi prakarsa, kreativitas dan kemandirian sesuai dengan bakat, minat dan perkembangan fisik serta psikologis peserta didik. 
Tidak berbeda dengan siswa yang mengikuti di sekolah biasa, pada sekolah luar biasa pun diperlukan strategi pembelajaran yang cocok untuk siswa autis dalam proses pembelajaran Matematika. Dengan pemilihan strategi yang cocok, nantinya anak akan mudah untuk menangkap materi dari pembelajaran Matematika sehingga tujuan pembelajaran dapat tercapai dengan efektif.

\section{KAJIAN PUSTAKA}

Istilah autisme dalam kenyataannya terdapat bermacam-macam, seperti: autis merupakan gangguan kognitif, tingkah laku dan gangguan verbal (bahasa). Dan autistik adalah gejala atau perilaku yang tampak, sedangkan autisme adalah orang yang mengalami gangguaan kognitif, tingkah laku dan verbal (bahasa). Istilah "autisme" pertama kali diperkenalkan pada tahun 1943 oleh Kanner secara etimologis kata "autisme" berasal dari "auto" dan "isme". Auto berarti diri sendiri, sedangkan "isme" berarti aliran atau paham. Menurut Kanner (dalam Kamid 2011:83) menemukan anakanak yang mempunyai sekumpulan tingkah laku berbeda yang kemudian dinamakan sindrom early childhood autisme.

Kanner (dalam Jamaris, 2003:81) mengatakan autisme adalah anak yang mengalami outstanding fundemental disorder sehingga tidak mampu melakukan interaksi dengan lingkungannya. Anak-anak dengan gangguan autistik ini cenderung menampakkan gejala gangguan komunikasi, tidak mampu melakukan komunikasi baik verbal maupun non verbal, berpotensi menjadi hiperaktif. Dalam memberikan batasan autis ini seringkali terjadi kekeliruan, bahwa anak autis sama dengan anak tunagrahita, namun mereka rata-rata memiliki intelegensi rata-rata, dan bahkan berpeluang diatas rata-rata.

Jika ada reaksi biasanya reaksi ini tidak sesuai dengan situasi atau malahan tidak ada reaksi sama sekali. Mereka menghindari atau tidak berespon terhadap kontak sosial (pandangan mata, sentuhan kasih sayang, bermain dengan anak lain dan sebagainya).

Menurut Monk dkk, (dalam Joko, 2012:24) autistik berasal dari kata "Autos" yang berarti "Aku”. Dalam pengertian non ilmiah dapat diinterpretasikan bahwa semua anak yang mengarah pada dirinya sendiri disebut autistik. Menurut Tilton, (dalam Joko, 2012:24) bahwa pemberian nama autistik karena hal ini diyakini dari "keasyikan yang berlebihan" dalam dirinya sendiri. Jadi, autis dapat diartikan secara sederhana sebagai anak yang suka menyendiri atau asyik dengan dunianya sendiri. Sementara menurut Zelan (dalam Adriana 2007:88) berpendapat bahwa individu autistik berbeda dengan individu lain sehingga perlu 
didekati dengan pendekatan humanistik yang memandang mereka sebagai individu yang utuh dan unik.

Dari beberapa pendapat di atas, peneliti menyimpulkan bahwa anak autis merupakan anak yang sulit berinteraksi dengan lingkungannya, kesulitan berkomunikasi dengan orang lain, anak autis senang dengan dunianya sendiri dan anak autis memerlukan pendekatan khusus.

Sumber kesulitan bagi siswa autis SLB adalah tidak adanya karakter pembelajaran yang dapat digunakan secara tepat sehingga hal ini dapat menghambat pembelajaran Matematika. Indikasi yang mempengaruhi perkembangan untuk pemahaman Matematika adalah perhatian, proses kognitif, permasalahan tentang lemahnya memori atau daya ingat siswa. Guru merupakan variabel yang paling mempengaruhi dalam proses perancangan sebuah pembelajaran siswa autis. Pengaruh guru dapat beranjak dari pendapat mereka tentang apa yang seharusnya dipelajari oleh siswa, kapasitas mereka untuk memfasilitasi pembelajaran (penguasaan psikologi pendidikan dan metode mengajar), komitmen mereka terhadap profesi, keyakinan akan kemampuan siswa menangkap pelajaran, hingga latar belakang bidang keilmuan mata pelajaran yang ditempu, sehingga guru memberikan beberapa strategi pembelajaran yang tidak sama dengan siswa kelas normal.

\section{METODE PENELITIAN}

Penelitian ini dilaksanakan di Filial SLBN Bekasi Jaya tahun ajaran 2015/2016 pada mata pelajaran Matematika. Penelitian ini dilaksanakan pada bulan Maret 2016 sampai dengan Mei 2016. Waktu pelaksanaan penelitian dilakukan sesuai dengan jadwal mata pelajaran matematika di sekolah. Dalam penelitian ini yang menjadi subjek penelitian adalah siswa autis di sekolah Filial SLBN Bekasi Jaya sebanyak 1 siswa (subjek M) dikarenakan di dalam kelas tersebut hanya terdapat 1 Anak Autis.

Permasalahan yang akan dikaji oleh peneliti merupakan masalah yang bersifat sosial dan dinamis. Oleh karena itu, peneliti memilih menggunakan metode penelitian kualitatif untuk menentukan cara mencari, mengumpulkan, mengolah dan menganalisis data hasil penelitian tersebut. Penelitian kualitatif ini dapat digunakan untuk memahami interaksi sosial, misalnya dengan wawancara mendalam sehingga akan ditemukan pola-pola yang jelas.

Teknik pengumpulan data pada penelitian ini diperoleh dari hasil observasi, wawancara, dan dokumentasi. 


\section{Observasi}

Dalam penelitian ini, peneliti memilih observasi partisipan, yaitu suatu teknik pengamatan dimana peneliti ikut ambil bagian dalam kegiatan yang dilakukan oleh objek yang diselidiki. Observasi ini dilakukan dengan mengamati dan mencatat langsung terhadap objek penelitian, yaitu dengan mengamati kegiatan-kegiatan yang ada di sekolah Filial SLBN Bekasi Jaya. Aspek yang diamati meliputi :

a. Materi Pembelajaran

Kurikulum merupakan suatu peran penting dalam pendidikan. Kurikulum digunakan pada setiap sekolah, baik sekolah umum ataupun Sekolah Luar Biasa. Apakah pada Sekolah Luar Biasa mempunyai kurikulum tersendiri ataukah sama dengan kurikulum sekolah pada umumnya. Buku merupakah salah satu media yang digunakan guru dan siswa untuk belajar dan pembelajaran. Apakah buku yang digunakan guru dan siswa Autis di Sekolah Luar Biasa sama dengan buku yang digunakan di sekolah-sekolah pada umumnya. Materi Matematika apa saja yang diajarkan guru kepada siswa Autis. Dalam mengajar administrasi guru sangatlah penting. Apakah guru sudah mempersiapkan administrasi mengajarnya dengan baik dan bagaimana cara guru memberi penilaian untuk siswa Autis.

b. Proses Pembelajaran di Kelas

Metode pembelajaran yang dilakukan sangat mempengaruhi hasil dari proses belajar mengajar. Metode apa yang di gunakan guru Sekolah Luar Biasa untuk mengajar siswa Autis. Selain metode, mediapun mempengaruhi tingkat pemahaman siswa. Media apakah yang digunakan guru untuk mengajar, darimanakah media itu berasal. Apakah guru membuat sendiri atau dari sumber lain. Dalam proses belajar di dalam kelas adanya proses interaksi. Bagaimana proses interaksi antara guru dan siswa Autis. Setiap guru mengharapkan situasi kelas yang kondusif untuk belajar mengajar. Apakah di kelas tersebut tercipta suasana kelas yang kondusif atau sebaliknya. Proses belajar mengajar guru memberikan umpan balik kepada siswa. Umpan balik apa yang diberikan guru kepada siswa Autis.

c. Proses Pembelajaran di Luar Kelas

Kebosanan sering terjadi pada siswa yang sedang melaksanakan belajar pemelajaran, banyak metode yang dilakukan guru untuk menghilangkan kebosanan pada siswa-siswanya salah satunya dengan proses pembelajaran di luar kelas. Dengan memberikan metode proses pembelajaran di luar kelas dapat 
menghilangkan kebosanan pada siswa. Pengamatan juga akan dilakukan ketika pembelajaran dilakukan di luar kelas.

d. Tingkah Laku Siswa pada saat Pembelajaran

Dalam proses pembelajaaran matematika, sejak kelas dimulai sampai dengan kelas berakhir, segala tingkah laku atau kegiatan yang dilakukan siswa autis akan diamati dengan seksama.

e. Interaksi Sosial

Pengamatan tidak hanya dilakukan pada tingkah laku individu siswa autis melainkan juga terhadap interaksi sosial pada lingkungan sekitarnya. Interaksi sisial dapat meningkatkan komunikasi siswa, bagi siswa autis dengan berinteraksi ia akan lebih sedikit terbuka tidak hanya berdiam diri dengan dunianya. Begitupula interaksi guru dengan siswa, tidak hanya interaksi saat proses pembelajaran namun juga interaksi di luar akan diamati.

2. Wawancara

Dalam penelitian ini, peneliti melakukan wawancara mendalam untuk mengumpulkan informasi yang kompleks, yang sebagian besar berisi pendapat, sikap, dan pengalaman pribadi. Untuk menghindari kehilangan informasi, maka peneliti meminta ijin kepada informan untuk menggunakan alat perekam. Sebelum dilangsungkan wawancara mendalam, peneliti menjelaskan atau memberikan sekilas gambaran dan latar belakang secara ringkas dan jelas mengenai topik penelitian.

Beberapa hal yang perlu diperhatikan dalam melakukan wawancara, diantaranya adalah sebagai berikut :

a. Pewawancara hendaknya menghindari kata yang memiliki arti ganda, atau pun yang bersifat ambiguitas.

b. Pewawancara menghindari pertanyaan panjang yang mengandung banyak pertanyaan khusus. Pertanyaan yang panjang hendaknya dipecah menjadi beberapa pertanyaan baru.

c. Pewawancara hendaknya mengajukan pertanyaan yang konkrit dengan acuan waktu dan tempat yang jelas.

d. Dalam wawancara mengenai hal yang dapat membuat responden marah , malu atau canggung, gunakan kata atau kalimat yang dapat memperhalus. 


\section{Dokumentasi}

Dokumen menurut Sugiyono, (2012:240) merupakan catatan peristiwa yang sudah berlalu. Dokumen yang digunakan peneliti disini berupa foto, video, serta catatan lapangan mengenai situasi belajar Matematika anak autis. Hasil penelitian dari observasi dan wawancara akan semakin sah dan dapat dipercaya apabila didukung oleh foto-foto dan video.

\section{HASIL DAN PEMBAHASAN}

Dalam melaksanakan kegiatan pembelajaran Filial SLBN Bekasi Jaya memakai kurikulum 2013 sesuai yang diberikan pemerintah. perbedaan kurikulum 2013 yang digunakan di sekolah umum dan SLB ini terletak pada isi kurikulum tersebut, di SLB terdapat berbagai macam keberbedaan kemampuan, baik secara fisik, kognitif maupun afektif. Setiap anak ABK mempunyai kurikulum tersendiri karena beda berkebutuhannya beda cara mengajarnya. Buku untuk sekolah umum berbeda dengan buku pada sekolah luar biasa, buku yang digunakan siswa Autis di Filial SLBN Bekasi jaya merupakan buku khusus untuk anak autis yang didalamnya terdapat materi-materi sesuai kurikulum hanya saja tidak menggunakan angka seperti sekolah umum.

Hasil observasi oleh peneliti didapat bahwa pemahaman konsep hitung perkalian pada siswa autis di kelas 11 Filial SLBN Bekasi Jaya masih kurang memahami terhadap mata pelajaran Matematika. Saat memulai pembelajaran siswa autis duduk dengan tenang memperhatikan guru yang sedang menjelaskan materi. Lalu guru memberikan soal latihan kepada siswa kelas 11 Filial SLBN Bekasi Jaya dan siswa autis menulis apa yang ada di papan tulis, tetapi saat guru tidak membimbingnya belajar maka ia akan terus menghapus apa yang sudah ia tulis. Maka dari itu guru memberikan waktu khusus untuk membimbing siswa autis belajar dan berhitung perkalian.

Saat menghitung perkalian siswa autis memiliki masalah dalam berhitung perkalian, maka guru membimbingnya dengan cara menambahkan angkanya. Saat guru memberikan soal 92 x 3 maka guru membimbing untuk siswa autis menulis 92 sebanyak tiga kali dengan menyusun kebawah, lalu guru membimbing siswa autis untuk menjumlahkan 92 sebanyak 2 kali dan hasilnya ditambahkan lagi dengan 92, saat menjumlahkan susun kebawah guru menjelaskannya dengan menggunakan media yang ada disekitar kelas seperti pensil, pulpen, dan penghapus. setelah selesai dihitung siswa autis menulis jawabannya ditemapatnya. Tetapi jika guru hanya memberikan caranya tampa membimbingnya dalamberhitung maka siswa 
autis tersebut akan menghitung dengan sesuka hatinya saja atau bisa dikatakan kurang tepat, ia akan menghitung semaunya saja tanpa memperdulikan apakah hasilnya benar atau tidak.

Beberapa kali guru mengajak siswa untuk mengerjakan latihan soal langsung di papan tulis, siswa autis sangat senang apabila ia diberi kesempatan untuk mengerjakan soal langsung di papan tulis ia merasa dihargai oleh guru dan teman-temannya jika ia diminta guru untuk maju mengerjakan soal latihan di papan tulis. Ada rasa kepuasan dalam dirinya jika ia mengerjakan langsung di papan tulis walaupun jawaban yang ia kerjakan belum tepat terhadap hasil jawaban yang benar tetapi ia tetap merasa puas dan dihargai.

Pendekatan dan komunikasi guru dengan siswa autis sangan intens, siswa autis hanya mau berkomunikasi dengan guru kelasnya atau dengan orang yang ia kenal saja. Cara guru melakukan pendekatan dengan siswa autis yaitu dengan kelembutan dan tidak ada jarak antara guru dengan siswa tetapi menciptakan pendekatan seperti antara kakak dengan adik, dengan pendekatan tersebut siswa autis merasa ia sedang belajar dengan seorang kakak. Walaupun demikian siswa autis sangat menghormati dan menghargai gurunya.

Saat pembelajaran berlangsung ketika suasana kelas tidak kondusif untuk belajar, siswa autis tidak terpengaruh dengan hal tersebut, ia tidak mempedulikan temannya yang sedang bercanda ataupun mengobrol, ia tetap melanjutkan belajarnya. Apa saja yang guru tulis di papan tulis, oleh siswa autis selalu dicatat sama persis seperti yang ditulis oleh guru, semua yang ia kerjakan selalu dilakukan dengan hati. Semangat belajar siswa autis di mulai dari rumahnya, saat dirumah ia merasa nyaman, tidak terbebani maka ia akan semangat mengikuti pembelajaran di sekolah tetapi saat di rumah ia sudah malas untuk belajar ataupun ada hal yang membuat ia tidak nyaman maka perasaan tersebut akan terbawa sampai sekolah yang menyebabkan ia malas belajar dan sering marah-marah jika di paksa belajar oleh guru.

\section{SIMPULAN DAN SARAN}

Berdasarkan hasil penelitian dan pembahasan dapat disimpulkan bahwa subjek M yang duduk di kelas 11 di Filial SLBN Beksi Jaya dalam pembelajaran Matematika sangat membutuhkan bimbingan khusus dari guru kelas. Ketika menyelesaikan soal latihan, ia tidak dapat mengerjakan sendiri soal tersebut dengan tepat. Sehingga setiap harinya guru selalu memberikan tambahan waktu khusus untuk membantunya belajar serta mengerjakan soal.

Guru memberikan bimbingan khusus untuk siswa autis kelas 11 di Filial SLBN Bekasi Jaya. Ia membimbing cara menghitung perkalian dengan cara menjumlahkan susunan kebawah. Akan tetapi jika siswa hanya diberikan caranya saja tidak dibimbing atau 
didampingi maka siswa autis tersebut akan menghitung dengan sesuka hatinya tanpa memperhatikan hasilnya benar atau salah.

Berdasarkan kesimpulan di atas, maka dapat disampaikan saran sebagai berikut :

1. Bagi Guru

a. Guru dalam pembelajaran matematika pada anak autis, lebih baik menggunakan media dalam upaya mengoptimalkan hasil pembelajaran matematika pada siswa.

b. Guru sebaiknya lebih banyak memberikan stimulus yang sesuai dengan kemampuan berhitung siswa, sehingga siswa akan lebih senang belajar matematika.

c. Perlu adanya kerjasama antara guru dan orangtua dalam rangka mengembangkan kemampuan berhitung siswa yang nanti ditindaklanjuti secara konsisten di rumah.

\section{Bagi Sekolah}

Untuk mengembangkan kemampuan belajar berhitung pada anak, sekolah hendaknya menciptakan lingkungan belajar yang kondusif yaitu memberikan media pembelajaran yang di butuhkan oleh siswa.

\section{DAFTAR PUSTAKA}

Ginanjar, Adriana Soekandar. (2007). "Memahami Spektrum Autistik Secara Holistik”. Sosial Humaniora. Vol 11. No 2.

Jamaris, Martini. (2003). Perkembangan dan Pengembangan Anak Usia Taman Kanakkanak. Jakarta : Universitas Negeri Jakarta.

Kamid. (2011). "Pemerolehan Pengetahuan Matematika Bagi Siswa Autis Pada Permulaan Bangku Sekolah". Jurnal Edumatica. Vol 01 No 02.

Yuwono, Joko. (2012). Memahami Anak Utistik. Bandung : Alfabeta.

\section{UCAPAN TERIMAKASIH}

Ucapan terima kasih kami sampaikan kepada Direktorat Jenderal Pendidikan Tinggi (Dirjen DIKTI) yang telah membiayai sepenuhnya penelitian ini dalam Program Kreatifitas Mahasiswa (PKM) dalam Skema Penelitian tahun 2015. 